\title{
Michał Grzeszczyk
}

Uniwersytet Warmińsko-Mazurski w Olsztynie

grzeszczykmichal@gmail.com

\section{Dyskryminacja w nawiązaniu stosunku pracy ze względu na karalność}

\author{
Discrimination in Employment Relationships Due to Criminality
}

\section{STRESZCZENIE}

Prawa pracownika są chronione przez Kodeks pracy i inne przepisy prawa pracy. Funkcję ochronną tej gałęzi prawa realizują m.in. przepisy dotyczące zakazu dyskryminacji. W pewnych okolicznościach przepisy przewidują ochronę prawną również dla kandydatów na pracowników, wskazując, czego potencjalny pracodawca może od kandydata żądać, jak powinien się w stosunku do niego zachować oraz jakie są dozwolone kryteria oceny poszukującego pracy w toku rekrutacji na dane stanowisko. Do dyskryminacji może zatem dochodzić już na etapie poszukiwania pracy przez potencjalnego pracownika, w szczególności podczas postępowania rekrutacyjnego. Kodeks pracy zawiera otwarty katalog przyczyn dyskryminacyjnych, w związku z czym niejednokrotnie pojawiają się wątpliwości, czy działanie pracodawcy nosi znamiona dyskryminacji czy też jest działaniem dopuszczalnym. Z uwagi na to zasadna jest próba odpowiedzi na pytanie, czy dopuszczalne jest różnicowanie sytuacji kandydatów do pracy przy nawiązaniu stosunku pracy ze względu na uprzednią karalność. Pozwoli to wyznaczyć relację między dyskrecjonalną władzą pracodawcy do wyboru najlepszego kandydata na dane stanowisko a obowiązkiem równego traktowania wszystkich potencjalnych pracowników, w tym ze względu na treść ich karty karnej.

Słowa kluczowe: prawo pracy; dyskryminacja; karalność; skazanie; rekrutacja

\section{DYSKRYMINACJA W ZATRUDNIENIU}

Prawo pracy pełni przede wszystkim rolę ochronną. Ustanawia minimum praw, które przysługują pracownikowi oraz maksimum obowiązków, jakie można na niego nałożyć. Funkcja ta jest realizowana przez szereg zasad prawa pracy oraz instytucji (zarówno prawa pracy, jak i instytucji państwowych). Ochronna 
funkcja prawa pracy już od momentu rozpoczęcia przebiegu rekrutacji na stanowisko pracy znajduje swój wyraz m.in. w przepisach art. $11^{2 \mathrm{i}} 11^{3}$ Kodeksu pracy $^{1}$ oraz w rozdziale $2 \mathrm{a}$ działu I k.p. pt. Równe traktowanie $w$ zatrudnieniu, a w szczególności w przepisie art. $18^{3 a} \S 1$ k.p.

Funkcję ochronną pełni również prawo karne. Należałoby zatem zastanowić się, czy fakt prawomocnego skazania wyrokiem sądu karnego może mieć znaczenie w procesie rekrutacyjnym, a zatem czy dopuszczalne jest różnicowanie sytuacji kandydatów na pracowników z uwagi na karalność, bez narażenia się na zarzut stosowania działań dyskryminacyjnych.

Równość winna być rozumiana jako identyczność, jednakowość w traktowaniu. Wyjątki od obowiązku jednakowego traktowania dopuszcza się tylko i wyłącznie $\mathrm{w}$ celu zagwarantowania równouprawnienia. W polskim prawie pracy pojęcia równego traktowania i dyskryminacji są w pewnym zakresie stosowane zamiennie ${ }^{2}$.

Równość wobec prawa nie oznacza jednakowych praw i obowiązków wobec każdego pracownika. O naruszeniu zasady równego traktowania w zatrudnieniu można mówić tylko w stosunku do pracowników, którzy wykonują podobną pracę i mają identyczne cechy podmiotowe. Problem równości w prawie pracy nie polega zatem na całkowitym zakazie różnicowania uprawnień pracowników, lecz na prawidłowym i sprawiedliwym doborze kryteriów tego różnicowania. Nierówne traktowanie może być uznane za dyskryminacyjne, gdy jest ono pozbawione obiektywnego i rozsądnego usprawiedliwienia ${ }^{3}$.

Zgodnie $\mathrm{z}$ art. $11^{3}$ k.p. jakakolwiek dyskryminacja w zatrudnieniu - bezpośrednia lub pośrednia, w szczególności ze względu na płeć, wiek, niepełnosprawność, rasę, religię, narodowość, przekonania polityczne, przynależność związkową, pochodzenie etniczne, wyznanie, orientację seksualną, a także ze względu na zatrudnienie na czas określony lub nieokreślony albo w pełnym lub niepełnym wymiarze czasu pracy - jest niedopuszczalna. Przepis art. $18^{3 a} \S 1$ k.p. stanowi, że pracownicy powinni być równo traktowani w zakresie nawiązania i rozwiązania stosunku pracy, warunków zatrudnienia, awansowania oraz dostępu do szkolenia w celu podnoszenia kwalifikacji zawodowych, w szczególności bez względu na płeć, wiek, niepełnosprawność, rasę, religię, narodowość, przekonania polityczne, przynależność związkową, pochodzenie etniczne, wyznanie, orientację seksualną oraz bez względu na zatrudnienie na czas określony lub nieokreślony albo w pełnym lub niepełnym wymiarze czasu pracy.

${ }^{1}$ Ustawa z dnia 26 czerwca 1974 r. - Kodeks pracy (Dz.U. z 1974 r., nr 24, poz. 141), dalej jako: k.p.

2 A. Lankamer, P. Potocka-Szmoń, Dyskryminacja w miejscu pracy. Poradnik dla pracodawcy i pracownika, Gdańsk 2006, s. 11.

3 J. Skoczyński, Zasada równego traktowania pracowników, „Praca i Zabezpieczenie Społeczne" 1999, nr 7-8, s. 4. 
Wskazanie w przepisie art. $18^{3 a} \S 1$ k.p., że chodzi również o równe traktowanie w zakresie nawiązania stosunku pracy, przesądza w sposób bezapelacyjny, że do dyskryminacji może dochodzić już na etapie samej rekrutacji ${ }^{4}$. Podobnie $\mathrm{w}$ art. $18^{3 \mathrm{~b}} \S 1$ k.p. wyszczególniono, że pojęcie dyskryminacji odnosi się też do odmowy nawiązania stosunku pracy, co jednoznacznie potwierdza powyższą tezę. W ten sam sposób trzeba rozumieć sformułowanie „dyskryminacja w zatrudnieniu" $\mathrm{z}$ art. $11^{3}$ k.p., albowiem rozdział $2 \mathrm{a}$ działu I k.p. jest rozwinięciem zasady wyrażonej w wyżej wymienionym przepisie ${ }^{5}$.

Uważa się, że kryteria, które zostały wymienione w Kodeksie pracy, to katalog przykładowy i otwarty ${ }^{6}$, a do zakazanych kryteriów należy zaliczyć także inne okoliczności, takie jak np.: stan zdrowia, stan rodzinny, stan majątkowy, stan cywilny, pochodzenie społeczne, wygląd, ojcostwo, przynależność do organizacji, stopień wojskowy, rodzicielstwo nieślubnego dziecka czy miejsce zamieszkania?. Teoretycznie zatem nie ma przeszkód, by katalog ten rozszerzyć jeszcze bardziej, co oznacza, że może dojść do sytuacji, w której pracownik będzie traktowany nierówno również z innych - niewymienionych $\mathrm{w}$ niniejszym przepisie - przyczyn, w tym ze względu na jego uprzednią karalność ${ }^{8}$.

Zgodzić się należy z S.W. Ciupą, który dokonał podziału kryteriów dyskryminacji na dwie grupy. W jednej grupie znalazły się ,kryteria ustawowe”, nazywane przez autora „,zarną listą”, w drugiej zaś „kryteria pozaustawowe”, których zbiór określił mianem „białej listy”. Na „czarnej liście” zostały umieszczone te kryteria kodeksowe, ze względu na które różnicowanie sytuacji kandydatów do pracy praktycznie w każdym wypadku będzie uznane za dyskryminujące. $\mathrm{Na}$ drugiej liście (tj. „liście białej”) pojawiły się kryteria, których przypadki użycia mogą stwarzać podejrzenia, że został naruszony zakaz dyskryminacji, ale takowe ustalenia będą uzależnione od przeprowadzenia analizy całokształtu konkretnych okoliczności związanych z selekcją i rekrutacją. Na „białej liście” autor umieścił sytuację życiową, osobistą, rodzinną, finansową, majątkową, a także

${ }^{4}$ Tak też: A. Roguska-Kikoła, M. Piwowarska-Reszka, Mobbing $i$ dyskryminacja $w$ stosunkach pracy. Zagadnienia praktyczne, Warszawa 2014, s. 86-97; inaczej: J. Król, Nowelizacja Kodeksu pracy dotyczaca równego traktowania w zatrudnieniu na tle regulacji wspólnotowych, „Radca Prawny” 2004, nr 4, s. 94 i n.

5 A. Sobczyk, [w:] Kodeks pracy. Komentarz, red. A. Sobczyk, Warszawa 2014, s. 47.

${ }^{6}$ W przeciwieństwie do katalogu zawartego w dyrektywie Rady 2000/78/WE z dnia 27 listopada 2000 r. ustanawiającej ogólne warunki ramowe równego traktowania w zakresie zatrudnienia i pracy (Dz.Urz. WE L 303 z dnia 2 grudnia 2000 r.).

${ }^{7}$ Podręcznik europejskiego prawa o niedyskryminacji, Agencja Praw Podstawowych Unii Europejskiej 2010, Rada Europy 2012, s. 128.

8 B. Raczkowski, Dyskryminacja bez dyskryminacji. Dylematy. Rozbieżność prawa polskiego i unijnego, „Gazeta Prawna” 2004, nr 122. Zob. także: B. Lenart, Dyskryminacja w pracy bezwzględnie zakazana. Przepisy ogólne. Równe traktowanie w zatrudnieniu, „Gazeta Prawna” 2004, nr 24. 
takie kryteria, jak wymóg posiadania określonego statusu lub wykształcenia czy wymóg posiadania określonych cech osobowych ${ }^{9}$.

Na uwadze zatem trzeba mieć, na co zwróciłem uwagę powyżej, że nie każde nierówne traktowanie w zatrudnieniu będzie mogło być poczytane za działanie dyskryminacyjne. Funkcja ochronna prawa pracy nie jest równoznaczna ochronie absolutnej. Należy podjąć próbę odpowiedzi, czy uprzednia karalność osoby ubiegającej się o pracę może być poczytana za obiektywne (przynajmniej w pewnych sytuacjach) kryterium usprawiedliwiające różnicowanie sytuacji osób ubiegających się o zatrudnienie, a więc czy uprzednią karalność można umieścić na „białej liście” w rozumieniu S.W. Ciupy.

\section{ŻĄDANIE PRZEDŁOŻENIA ZAŚWIADCZENIA O NIEKARALNOŚCI}

Rekrutacja to proces przyciągania osób, które są potencjalnie zainteresowane objęciem danego stanowiska. Następnie spośród zainteresowanych wybiera się jedną osobę lub kilka, by złożyć im ofertę pracy ${ }^{10}$. Celem jest obsadzenie wolnych stanowisk osobami, które są odpowiednie, tj. takimi, które w przyszłości będą w sposób należyty wywiązywać się z powierzonych im obowiązków ${ }^{11}$.

Proces rekrutacyjny trzeba zdefiniować jako zespół czynności, które mają na celu zgromadzenie danych osobowych oraz innych informacji od kandydatów ubiegających się o pracę, prowadzący do wyboru najbardziej odpowiedniej osoby na dane stanowisko pracy. W ramach procesu rekrutacyjnego mamy do czynienia $\mathrm{z}$ dwiema zasadniczymi czynnościami, tj. gromadzeniem dokumentów w formie papierowej od kandydatów (list motywacyjny i CV) oraz przeprowadzeniem rozmowy kwalifikacyjnej. Niekiedy może się pojawić potrzeba przeprowadzenia również innych czynności pomagających przy wyborze pracownika (takich jak np. testy psychologiczne) ${ }^{12}$.

W procesie selekcji i rekrutacji kandydatów do dyskryminacji może prowadzić zarówno samo zastosowanie kryteriów dyskryminacyjnych, jak i podejmowanie na każdym $\mathrm{z}$ etapów procesu naboru decyzji, których podstawą są zakazane kryteria (dyskryminacja bezpośrednia) lub kryteria, które teoretycznie są neutralne, ale de facto mogą prowadzić do dyskryminacji pewnych osób (dyskryminacja pośrednia) ${ }^{13}$.

${ }^{9}$ S.W. Ciupa, Naruszenie zakazu dyskryminacji w zatrudnieniu w praktyce korzystania z ogłoszeń rekrutacyjnych, cz. 1: Dyskryminacja ze względu na pteć, wiek, niepetnosprawność, wymóg spetnienia określonych obowiązków lub innych rygorów, „Praca i Zabezpieczenie Społeczne” 2006, nr 11, s. 582.

${ }^{10}$ B. Jamka, Kierowanie kadrami: pozyskiwanie i rozwój pracowników, Warszawa 1997, s. 35.

${ }^{11}$ M. Suchar, Rekrutacja i selekcja personelu, Warszawa 2005, s. 1-4.

12 A. Kowalska, Pracownik w firmie od przyjęcia do zwolnienia, Warszawa 2013, s. 15.

13 J.A. Suchar, Jak uniknąć dyskryminacji w procesie rekrutacji i selekcji pracowników, Gdańsk 2013, s. 19. 
Powszechnym zjawiskiem jest wymaganie przez pracodawcę - wraz z CV, listem motywacyjnym i innymi dokumentami - także zaświadczenia o niekaralności z Krajowego Rejestru Karnego (KRK). By ocenić prawidłowość tego zjawiska, niezbędne jest odczytanie nałożonych przez ustawodawcę ram, które zakreślają obowiązki informacyjne osoby ubiegającej się o zatrudnienie.

Zgodnie z art. 51 ust. 1 Konstytucji ${ }^{14}$ nikt nie może być obowiązany inaczej niż na podstawie ustawy do ujawniania informacji dotyczących jego osoby. I choć wydaje się, że przepis ten stanowi ograniczenie, to jednak właśnie z niego wywodzi się niekiedy wolność rozpowszechniania i przekazywania informacji15.

Udostępnianie danych osobowych przez kandydata na stanowisko pracy normuje przepis art. $22^{1} \mathrm{k}$.p. Jego celem jest zapobieżenie nadużywania przez pracodawcę prawa do gromadzenia informacji na temat pracownika. Wprawdzie z uwagi na szeroki zakres stosunku pracy pracodawca winien być uprawniony do pozyskiwania informacji o pracowniku, jednak uprawnienie to nie może być nieograniczone. Wskutek wprowadzenia tego przepisu na mocy ustawy z dnia 14 listopada 2003 r. o zmianie ustawy - Kodeks pracy oraz o zmianie niektórych innych ustaw ${ }^{16}$ została wyznaczona granica naruszania sfery prywatności osoby ubiegającej się o zatrudnienie oraz ochrona przed niedozwolonym pozyskiwaniem danych ${ }^{17}$.

Udostępnienie danych osobowych następuje w formie złożenia dokumentów, w tym zwłaszcza kwestionariusza kandydata do pracy, a także świadectwa pracy czy dokumentów stwierdzających kwalifikacje zawodowe ${ }^{18}$.

Zgodnie z przepisem art. $22^{1} \S 1$ k.p. pracodawca ma prawo żądać od osoby ubiegającej się o zatrudnienie podania danych osobowych obejmujących: imię (imiona) i nazwisko, imiona rodziców, datę urodzenia, miejsce zamieszkania (adres do korespondencji), wykształcenie oraz przebieg dotychczasowego zatrudnienia. Zgodnie z $\S 4$ przedmiotowego artykułu pracodawca może żądać podania innych danych osobowych niż określone w $\S 1$ i 2 , jeżeli obowiązek ich podania wynika z odrębnych przepisów.

Jako przykład przepisu szczególnego, który upoważnia pracodawcę do żądania informacji stanowiących tajemnicę osobistą (wrażliwe dane osobowe), wskazuje się regulacje, które pośród rygorów selekcyjnych wymieniają niekaralność.

${ }^{14}$ Konstytucja Rzeczypospolitej Polskiej z dnia 2 kwietnia 1997 r. uchwalona przez Zgromadzenie Narodowe w dniu 2 kwietnia 1997 r., przyjęta przez Naród w referendum konstytucyjnym w dniu 25 maja 1997 r., podpisana przez Prezydenta Rzeczypospolitej Polskiej w dniu 16 lipca 1997 r. (Dz.U. z 1997 r., nr 78, poz. 483).

${ }_{15}$ Por. wyrok Trybunału Konstytucyjnego, U 3/01, OTK-A 2002/1/3, zgodnie z którym ,art. 51 ust. 1 Konstytucji potwierdza prawo jednostki do samodzielnego decydowania o ujawnianiu informacji o sobie". Tak też: A. Drozd, Ochrona danych osobowych pracownika (kandydata) po nowelizacji kodeksu pracy, „Praca i Zabezpieczenie Społeczne” 2004, nr 1, s. 25.

${ }^{16}$ Dz.U., nr 213, poz. 2081.

17 W. Cajsel, Kodeks pracy. Komentarz, Warszawa 2007, s. 69.

${ }^{18}$ L. Florek, Prawo pracy, Warszawa 2015, s. 64. 
Art. 6 pkt 10 ustawy z dnia 24 maja 2000 r. o Krajowym Rejestrze Karnym ${ }^{19}$ przyznaje pracodawcom prawo do uzyskania informacji o osobach notyfikowanych $\mathrm{w}$ rejestrze $\mathrm{w}$ zakresie niezbędnym do zatrudnienia pracownika, co do którego z przepisów ustawy wynika m.in. wymóg niekaralności. Przykładem takiej regulacji może być przepis art. 4 ustawy z dnia 21 listopada 2008 r. o służbie cywilnej ${ }^{20}$, który przy zatrudnianiu osób w służbie cywilnej wprowadza wymóg niekaralności za przestępstwo popełnione umyślnie lub przestępstwo skarbowe. W takim zakresie pracodawca jest uprawniony do wystąpienia do Krajowego Rejestru Karnego z zapytaniem o karalność kandydata do pracy. Pracodawca w tym przypadku uzyska informacje dotyczące karalności kandydata do pracy, ale jedynie za przestępstwa popełnione umyślnie lub przestępstwa skarbowe.

Niemniej w sytuacji, gdy dana regulacja wprowadza wymóg niekaralności (często doprecyzowując, o jakie przestępstwa chodzi), odpada zupełnie problem dyskryminacji ze względu na skazanie za te przestępstwa. Nie może być bowiem mowy o dyskryminacji za karalność, jeśli to ustawodawca nakłada na pracodawcę prawny obowiązek zbadania, w danym zakresie, karalności kandydatów do pracy.

Zupełnie inaczej problem ten wygląda w tych przypadkach, gdy przepis ustawowy nie wprowadza wymogu niekaralności. Pracodawca nie ma wówczas możliwości zwrócić się bezpośrednio do KRK z zapytaniem o tzw. kartę karną kandydata do pracy.

Czy w sytuacji, gdy karalność w sposób oczywisty podnosi ryzyko zatrudnienia nieodpowiedniej osoby na danym stanowisku (np. w związku z powierzeniem pieczy nad mieniem), pracodawca ma całkowicie zamkniętą drogę do pozyskania informacji o karalności kandydata za przestępstwa przeciwko mieniu? Generalny Inspektor Ochrony Danych Osobowych uważa, że droga pracodawcy jest w tym przypadku zamknięta, nawet jeśli pracownik wyraziłby na to zgodę na piśmie ${ }^{21}$. Nie ulega jednak wątpliwości, że brak ustawowego wymogu niekaralności zamyka jedynie możliwość bezpośredniego zwrócenia się z zapytaniem do KRK, natomiast nie zamyka całkowicie możliwości pozyskania informacji o karalności kandydata do pracy ${ }^{22}$.

Należy zauważyć, że przepis art. $22^{1}$ k.p. reguluje zasady, na jakich pracodawca może uzyskiwać informacje o pracowniku od niego samego. Pracodawcy nie będą zatem obowiązywały regulacje zawarte w tym przepisie, jeżeli dane osobowe pracownika zostaną mu przekazane przez osobę trzecią. Nie uchyla to wprawdzie ochrony pracownika wynikającej z przysługującego mu przecież prawa do prywatności, lecz dla oceny, czy doszło do naruszenia tego prawa, konieczna

19 Dz.U. z 2012 r., poz. 654 ze zm.

${ }^{20}$ Dz.U. z 2014 r., poz. 1111 ze zm.

${ }^{21}$ I. Walencik, Sprawdzanie niekaralności, ,Rzeczpospolita” 2004 (10 maja).

${ }^{22}$ A. Patulski, [w:] A. Patulski, G. Orłowski, Kodeks pracy 2015. Komentarz dla praktyków, Gdańsk 2015, s. 126-127. 
jest analiza przepisów ustawy o ochronie danych osobowych, która w takiej sytuacji znajdzie zastosowanie ${ }^{23}$.

Analogicznie będzie wyglądać sytuacja, gdy pracodawca wejdzie w posiadanie danych informacji o pracowniku wskutek własnego działania. W epoce, w której gros informacji jest publikowane samodzielnie przez pracowników, taka sytuacja nie powinna dziwić i będzie się zdarzać coraz częściej. Już w chwili obecnej część pracodawców w czasie przeprowadzania rekrutacji sprawdza konta kandydatów do pracy na portalach społecznościowych, takich jak chociażby Facebook. Jakkolwiek dwuznaczne etycznie, takie działania nie stanowią wyjąt$\mathrm{ku}$, a wręcz nabierają cechy regularności.

Należy pamiętać, że prawo pracy, tak jak cały system prawa prywatnego, opierając się na zasadzie autonomii woli stron, musi uznawać szeroko rozumianą wolność komunikowania się. Dobór pracownika może zatem wiązać się również z wymianą informacji wykraczających poza te wskazane w art. $22^{1}$ k.p. Każdy kandydat do pracy zdaje sobie sprawę, że ograniczając swoje informacje, będzie miał mniejsze szanse w konfrontacji z innymi zainteresowanymi, którzy opanowawszy sztukę autoprezentacji, nie będą ograniczać się wyłącznie do danych, których pracodawca może od nich żądać. Proces rekrutacyjny niewątpliwie uprawnia pracodawcę do przeprowadzania rozmów kwalifikacyjnych, podczas których zadaje pytania kandydatom do pracy, w tym takie, które wykraczają poza art. $22^{1}$ k.p. Odpowiadanie na nie, o ile oczywiście są one uzasadnione celem zatrudnienia na konkretnym stanowisku, wymaga zgody zainteresowanego na ich ujawnienie ${ }^{24}$. Oczywiście nie oznacza to akceptacji wszelkich pytań, a szczególnie tych, które nie mają żadnego związku z danym rodzajem pracy czy świadczących o dyskryminacyjnych praktykach. Komunikowanie się przez pracodawcę z kandydatem na dane stanowisko, w tym przekazywanie danych wykraczających poza te wskazane $\mathrm{w}$ art. $22^{1}$ k.p., jest niewątpliwie koniecznością, która umożliwia dokonanie świadomego wyboru przez pracodawcę, a akceptowaną przez osobę poszukującą zatrudnienia. Osoba taka musi być bowiem świadoma, że pracodawca nie może dokonywać wyboru najlepszego kandydata do pracy, porównując jedynie imiona, nazwiska, dyplomy czy świadectwa pracy zainteresowanych ${ }^{25}$.

Pogląd taki prezentuje m.in. M. Wujczyk, wskazując, że przepis art. $22^{1}$ k.p. stanowi ograniczenie do żądania od pracownika podania danych osobowych, lecz nie wyklucza uzyskania ich na innej podstawie. W tym względzie autor wska-

${ }^{23}$ W. Sanetra, [w:] J. Iwulski, W. Sanetra, Komentarz do Kodeksu pracy, Warszawa 2009, s. 195.

${ }^{24}$ Tak M. Wujczyk (Prawo pracownika do ochrony prywatności, Warszawa 2012, s. 173), według którego pracodawca powinien w przypadku otrzymania informacji wykraczających poza przepis art. 221 k.p. wystąpić o udzielenie mu zgody na przetwarzanie danych osobowych, informacje te zwrócić albo zniszczyć.

${ }^{25}$ A. Patulski, op. cit., s. 127-128. 
zuje na znaczenie słowa ,żądać”: 'kategorycznie domagać się czegoś’26. Zdaniem M. Wujczyka zostało ono użyte $\mathrm{w}$ celu zwrócenia uwagi na istnienie prawnego obowiązku udzielenia informacji przez pracownika z jednej z strony, $\mathrm{z}$ drugiej zaś wskazania na zakaz domagania się innych informacji oraz wyciągania ewentualnych konsekwencji wynikających z odmowy. Nie zakazuje ono jednak wymiany informacji między stronami w ramach wolności komunikacji. Nie można a priori zakładać, że w stosunkach pracy zgoda pracownika bądź kandydata na stanowisko pracy nigdy nie będzie miała charakteru swobodnego. Sam fakt istnienia zależności między pracodawcą a pracownikiem (bądź kandydatem do pracy) nie oznacza automatycznie istnienia jakiegokolwiek przymusu. Słusznie autor zauważa, że występowanie o inne dane niż przewidziane $\mathrm{w}$ art $22^{1} \mathrm{k}$.p. nie zostało przez ustawodawcę uznane za wykroczenie przeciw prawom pracownika ${ }^{27}$. Trudno zaś bronić tezy, że miałoby to tym bardziej stanowić przestępstwo z art. 218 § 1a Kodeksu karnego ${ }^{28}$.

Czy jednak, w związku z ową wolnością komunikowania się, pracodawca jest uprawniony do zapytania pracownika, czy był karany, w sytuacji gdy ustawa nie zawiera wymogu niekaralności na danym stanowisku? Tak, pod pewnymi warunkami i nie w każdej sytuacji. Dotyczy to przede wszystkim okoliczności, gdy pracodawca ma uzasadniony interes w przedłożeniu przez kandydata do pracy odpowiedniej informacji z KRK, o czym w dalszej części niniejszego opracowania. Osoba taka, na mocy art. 7 ustawy o Krajowym Rejestrze Karnym, ma de facto nieograniczony dostęp do treści zapisów jej dotyczących ${ }^{29}$.

Prowadząc rozmowę kwalifikacyjną, pracodawca powinien wystrzegać się wszelkich pytań o charakterze zbyt osobistym, które nie są związane z pracą ${ }^{30}$. Nawet jeśli pytanie o charakterze osobistym, w tym o uprzednią karalność, będzie na tle danego stanowiska pracy uzasadnione, powinno się podchodzić do tych kwestii ostrożnie i z wyczuciem ${ }^{31}$.

\section{UPRZEDNIA KARALNOŚĆ JAKO PODSTAWA ODMOWY NAWIĄZANIA STOSUNKU PRACY}

Zgodnie z przepisem art. $18^{3 \mathrm{~b}} \S 1$ k.p. pkt 1 za naruszenie zasady równego traktowania $\mathrm{w}$ zatrudnieniu uważa się różnicowanie przez pracodawcę sytuacji pracownika $\mathrm{z}$ jednej lub kilku przyczyn określonych $\mathrm{w}$ art. $18^{3 \mathrm{a}} \S 1$ k.p., którego

\footnotetext{
${ }^{26}$ http://sjp.pwn.pl [dostęp: 12.09.2016].

${ }^{27}$ M. Wujczyk, Prawo pracownika..., s. 170-172.

${ }^{28}$ Ustawa z dnia 6 czerwca 1997 r. - Kodeks karny (Dz.U. z 1997 r., nr 88, poz. 553).

${ }^{29}$ A. Patulski, op. cit., s. 128-129.

${ }^{30}$ A. Kowalska, op. cit., s. 17.

${ }^{31}$ P. Ziółkowski, Zatrudnianie pracowników, [w:] Vademecum Głównego Księgowego, www. produkty.lex.pl/glowny-ksiegowy [dostęp: 10.10.2016].
} 
skutkiem jest m.in. odmowa nawiązania stosunku pracy, chyba że pracodawca udowodni, że kierował się obiektywnymi powodami. Zgodnie z § 2 pkt 1 tego artykułu zasady równego traktowania $\mathrm{w}$ zatrudnieniu nie naruszają działania proporcjonalne do osiągnięcia zgodnego z prawem celu różnicowania sytuacji pracownika, polegające na niezatrudnianiu pracownika z jednej lub kilku przyczyn określonych $w$ art. $18^{3 a} \S 1$, jeżeli rodzaj pracy lub warunki jej wykonywania powodują, że przyczyna lub przyczyny wymienione w tym przepisie są rzeczywistym i decydującym wymogiem zawodowym stawianym pracownikowi.

W orzecznictwie Trybunału Konstytucyjnego ${ }^{32}$ wskazuje się, że odstępstwa od zasady równego traktowania w zatrudnieniu są dopuszczalne, lecz pod warunkiem spełniania przesłanek: relewantności (bezpośredniego związku z celem i zasadniczą treścią przepisów, w których jest zawarta kontrolowana norma), proporcjonalności (waga interesu, któremu ma służyć różnicowanie sytuacji adresatów normy, musi pozostawać w odpowiedniej proporcji do wagi interesów, które zostaną naruszone przez nierówne traktowanie podmiotów podobnych) oraz istnienia związku z innymi zasadami, normami bądź wartościami konstytucyjnymi uzasadniającymi odmienne potraktowanie podmiotów podobnych ${ }^{33}$.

Trzeba także zauważyć, że w orzecznictwie sformułowano pogląd, iż nie będzie nosiło znamion dyskryminacji działanie wyrażające się w odmowie nawiązania stosunku pracy, jeśli skutecznie powołano się na przepis art. $18^{3 \mathrm{~b}} \S 2$ k.p. pkt 1, jako podstawę podając obowiązujące stosunki moralno-obyczajowe ${ }^{34}$.

Wskazuje się, że z uwagi na rodzaj pracy może być niezbędne np. zatrudnienie osób o konkretnie określonych cechach, co automatycznie wyklucza osoby nieposiadające danej - ważnej z uwagi na wymagania i uwarunkowania konkretnej pracy - cechy ${ }^{35}$. W przypadku, gdy osoba nie posiada pewnej cechy, która w sposób obiektywny jest wymagana przy wykonywaniu określonej pracy, odmowy nawiązania stosunku pracy z taką osobą nie można poczytywać za jakąkolwiek dyskryminację.

W wyroku z dnia 2 października 2012 r. ${ }^{36}$ Sąd Najwyższy stwierdził, że:

[...] dyskryminacją jest nieusprawiedliwione obiektywnymi powodami gorsze traktowanie pracownika ze względu na niezwiązane z wykonywaną pracą cechy lub właściwości dotyczące go osobiście $\mathrm{i}$ istotne ze społecznego punktu widzenia, przykładowo wymienione $\mathrm{w}$ art. $18^{3 \mathrm{a}} \S 1$ k.p., bądź ze względu na zatrudnienie na czas określony lub nieokreślony albo w pełnym lub niepełnym wymiarze czasu pracy.

${ }^{32}$ Por. orzeczenie Trybunału Konstytucyjnego z dnia 3 września 1996 r., K 10/96, OTK 1996, nr 4, poz. 33.

${ }^{33}$ K. Kędziora, K. Śmiszek, Dyskryminacja i mobbing $w$ zatrudnieniu, Warszawa 2010, s. 145.

${ }^{34}$ Por. postanowienie Sądu Najwyższego z dnia 11 kwietnia 2012 r., I PK 224/11, Lex nr 1220787.

${ }^{35}$ A. Roguska-Kikoła, M. Piwowarska-Reszka, op. cit., s. 144.

${ }^{36}$ II PK 82/12, OSNP 2013, nr 17-18, poz. 202. 
W ostatnim z przytoczonych wyroków clou stanowi stwierdzenie: „niezwiązane z wykony waną pracą cechy". A contrario nie będzie dyskryminacją różnicowanie sytuacji pracowników, gdy posiadanie danej cechy będzie miało związek $\mathrm{z}$ wykonywaną pracą.

Wydaje się, że uprzednia karalność pracownika może świadczyć o posiadaniu pewnych (zazwyczaj negatywnych) cech, które mogą być przez pracodawcę wysoce niepożądane. Rozpatrując ten problem, warto odwołać się do instytucji wypowiedzenia umowy o pracę. Wskazuje się, że utrata zaufania może być przyczyną uzasadniającą wypowiedzenie umowy o pracę na czas nieokreślony ${ }^{37}$. Kwestią zaufania zajął się Sąd Najwyższy w wyroku z dnia 4 lutego 2011 r. $^{38}$, gdzie podkreślił, że zaufanie to stan wyrażający się przekonaniem o możliwości polegania na kimś, czyli inaczej poczuciem pewności. Ponadto Sąd Najwyższy zaznaczył, że zaufanie stwarza szczególnego rodzaju więź między pracodawcą i pracownikiem, którą cechuje właśnie stan pewności. W wyroku Sądu Najwyższego z dnia 7 lutego 2013 r. ${ }^{39}$ zauważono, że zaufanie odgrywa jeszcze bardziej istotną rolę w stosunkach między pracodawcą lub osobami go reprezentującymi a osobami zajmującymi stanowiska kierownicze. $Z$ tego względu wypowiedzenie takim osobom umowy o pracę może być uzasadnione nawet mniej istotnymi przyczynami ${ }^{40}$. Generalne wskazanie na utratę zaufania pracodawcy do pracownika będzie uznane za zbyt ogólnikowe, a przyczynę trzeba dokładnie opisać, wyjaśniając $z$ czego konkretnie ona wynika ${ }^{41}$. W orzecznictwie kładzie się bowiem nacisk nie tyle na samą utratę zaufania, ile na przyczyny ją uzasadniające ${ }^{42}$.

Sąd Najwyższy wielokrotnie wypowiadał się na temat utraty zaufania i wiązał to również z faktem popełnienia przestępstwa. Wskazywano, że utrata zaufania może polegać np. na takich zachowaniach, w ramach których w ogóle nie dojdzie do naruszenia obowiązków pracowniczych (np. polegających na popełnieniu przestępstwa poza zakładem pracy) ${ }^{43}$. Ponadto uniewinnienie pracownika od zarzutu popełnienia danego przestępstwa wcale nie pozbawia sądu pracy możliwości uznania tego, że wypowiedzenie umowy o pracę było uzasadnione

37 A. Drozd, Wypowiedzenie stosunku pracy, Wrocław 2013, s. 75.

38 II PK 199/10, OSNP 2012, nr 7-8, poz. 90.

39 III PK 25/12, Lex nr 1360270.

${ }^{40}$ M. Wujczyk, [w:] Wypowiedzenie warunków pracy lub płacy w umownym stosunku pracy, red. Z. Góral, Warszawa 2015, s. 213-215.

${ }^{41}$ L. Brayshaw, A. Chrobot, E. Konior, A. Płucienik, G. Wanio, Derekrutacja, czyli jak skutecznie rozwiąać stosunek pracy, Warszawa 2015, s. 26-27.

42 Tak też: A. Leszczyńska, Utrata zaufania do pracownika jako przyczyna wypowiedzenia umowy o prace, [w:] Ochrona trwałości stosunku pracy w społecznej gospodarce rynkowej, red. G. Goździewicz, Warszawa 2010, s. 342.

43 Wyrok Sądu Najwyższego z dnia 25 listopada 1997 r., I PKN 385/97, OSNP 1998, nr 18, poz. 538; wyrok Sądu Najwyższego z dnia 14 października 2004 r., I PK 697/03, MPP 2005 , nr 10 , s. 10. 
z uwagi na utratę zaufania ${ }^{44}$. Czasami wystarczającym powodem do utraty przez pracodawcę zaufania do pracownika mogą być okoliczności usprawiedliwiające podejrzenie popełnienia przestępstwa, takie jak wszczęcie przeciwko pracownikowi dochodzenia, prowadzenie postępowania karnego przygotowawczego, łącznie $\mathrm{z}$ wniesieniem aktu oskarżenia ${ }^{45}$. W niektórych przypadkach (np. służby mundurowe) już nawet same kontakty pracownika z osobami, które są podejrzane o dane przestępstwo mogą stanowić podstawę do utraty zaufania, a w efekcie mogą być uzasadnioną przyczyną do wypowiedzenia stosunku pracy ${ }^{46}$. Należy jednak pamiętać, że nie chodzi o każde przestępstwo, lecz o przestępstwo, które będzie miało znaczenie dla pracodawcy w kontekście zaufania, jakim obdarza on swojego pracownika, a zatem $\mathrm{z}$ faktem popełnienia danego przestępstwa można wiązać utratę pewności między pracodawcą a pracownikiem. „Popełnienie przez pracownika przestępstwa może uniemożliwiać jego dalsze zatrudnianie na zajmowanym stanowisku także wówczas, gdy nie było dokonane na szkodę pracodawcy, jeżeli rodzaj przestępstwa ma związek z charakterem zatrudnienia pracownika" ${ }^{\prime 47}$.

Już tylko na marginesie trzeba zauważyć, że sam przepis art. $52 \S 1$ pkt 3 k.p. dopuszcza rozwiązanie umowy o pracę z pracownikiem bez wypowiedzenia (a zatem w trybie najbardziej dla pracownika dolegliwym) $\mathrm{z}$ winy pracownika $\mathrm{w}$ razie popełnienia przez niego w czasie trwania umowy o pracę przestępstwa, które uniemożliwia dalsze zatrudnianie go na zajmowanym stanowisku, jeżeli przestępstwo jest oczywiste lub zostało stwierdzone prawomocnym wyrokiem.

Posłużyłem się przykładem wypowiedzenia umowy o pracę ze względu na utratę zaufania do pracownika, ponieważ ma to znamienne znaczenie dla przeprowadzenia odpowiedniego wnioskowania. Wnioskowanie a fortiori, bo o nim tu mowa, przebiega według pewnego schematu (,Jeżeli A, to tym bardziej B”) i występuje w dwóch odmianach ${ }^{48}$. Pierwszą z nich, i de facto jedyną, która znajdzie tu zastosowanie, jest reguła a maiori ad minus, tj. wnioskowanie z większego na mniejsze, która w przypadku dozwolenia ${ }^{49}$ brzmi: jeżeli dozwolone jest A, to tym samym dozwolone jest wszystko, co oznacza mniej niż A (np. B) ${ }^{50}$.

${ }^{44}$ Wyrok Sądu Najwyższego z dnia 9 grudnia 1998 r., I PKN 498/98, OSNP 2000, nr 3, poz. 104.

${ }^{45}$ Wyrok Sądu Najwyższego z dnia 27 listopada 1997 r., I PKN 387/97, OSNP 1998, nr 19, poz. 569. Inaczej będzie w przypadku rozwiązania umowy o pracę bez wypowiedzenia, ponieważ przestępstwo w takiej sytuacji musi być oczywiste lub stwierdzone prawomocnym wyrokiem zatem jeśli nie jest oczywiste, samo wszczęcie dochodzenia lub śledztwa będzie niewystarczające.

${ }^{46}$ Wyrok Sądu Najwyższego z dnia 31 marca 2001 r., I PKN 212/00, OSNP 2002, nr 19, poz. 458.

${ }^{47}$ Wyrok Sądu Najwyższego z dnia 7 kwietnia 1999 r., I PKN 668/98, OSNP 2000, nr 11, poz. 429. W tym przypadku SN dopuścił ponadto rozwiązanie umowy o pracę bez wypowiedzenia.

${ }^{48}$ L. Morawski, Zasady wykładni prawa, Toruń 2010, s. 248.

${ }^{49}$ Może być stosowana również w przypadku nakazu.

${ }^{50}$ L. Leszczyński, Zagadnienia teorii stosowania prawa. Doktryna i tezy orzecznictwa, Kraków 2004, s. 247-248. 
Jeżeli chodzi o problem dopuszczalności stosowania wnioskowań a fortiori, to można przyjąć, że są one dopuszczalne na gruncie każdej gałęzi prawa i nie stosuje się do nich ograniczeń, z którymi mamy do czynienia przy analogii i argumentum a contrario. Podobnie jak inne dyrektywy wykładni, także wnioskowania a fortiori dopuszczają wyjątki i rezultat takiego procesu może być odrzucony albo z uwagi na względy logiczne (niepoprawność wnioskowania), albo merytoryczne, gdyż np. istnieją ważne racje, z którymi byłby sprzeczny rezultat wykładni argumentum a fortiori. Chodzi w tym przypadku o sprzeczność z podstawowymi zasadami prawa, ratio legis danej regulacji, gdy rezultat prowadziłby do konsekwencji absurdalnych, wyniku rażąco niesprawiedliwego lub nieracjonalnego, ewidentnej sprzeczności z konstytucją bądź oczywistego błędu legislacyjnego ${ }^{51}$.

$\mathrm{W}$ mojej ocenie $\mathrm{w}$ tym przypadku argumentum a maiori ad minus winna znaleźć zastosowanie. Skoro pracodawcy wolno rozwiązać za wypowiedzeniem stosunek pracy, wskazując jako przyczynę utratę zaufania spowodowaną popełnieniem przez pracownika przestępstwa, tym bardziej wolno mu z takim pracownikiem $\mathrm{w}$ ogóle stosunku pracy nie nawiązywać, skoro od początku, z uwagi na jego karalność za konkretne, mające związek z danym stanowiskiem pracy, przestępstwo, nie darzy go odpowiednim zaufaniem. Pracownik ma znacznie szersze prawa niż kandydat do pracy; ponadto zachodzi tu pewna chronologia - najpierw następuje nawiązanie stosunku pracy, a dopiero następnie stosunek ten można rozwiązać, dlatego samo nawiązanie stosunku pracy musi być rozumiane jako „mniej” w argumentacji a fortiori. Oczywiście zarówno w przypadku wypowiedzenia umowy o pracę, jak i etapu rekrutacyjnego przestępstwo musi pozostawać w związku z obowiązkami na danym stanowisku pracy i w sposób obiektywny powodować brak zaufania do danego pracownika.

W jakich przypadkach uprzednia karalność może zatem stanowić dopuszczalne kryterium zatrudniania pracowników? Uzyskując zgodę zainteresowanego zatrudnieniem na przedłożenie przez niego z KRK informacji o jego osobie, trzeba pamiętać, aby zakres tej informacji nie wykraczał poza rzeczywiste i uzasadnione potrzeby pracodawcy, które usprawiedliwiają ingerencję w sferę życia prywatnego rekrutowanego pracownika (za jego zgodą). W szczególności niedozwolone jest pytanie o te rodzaje przestępstw, których popełnienie przez daną osobę w żadnym przypadku nie wpłynie na ryzyko jej zatrudnienia na danym stanowisku, ponieważ nie pozostaje z tym zatrudnieniem $\mathrm{w}$ związku ${ }^{52}$.

M. Święcicki stoi na stanowisku, że sam fakt karalności nie może stanowić, w zasadzie, przeszkody przy zawieraniu umowy o pracę. Pod uwagę może być brany jedynie fakt niedawnego skazania za takie przestępstwo, które - gdyby

\footnotetext{
${ }^{51}$ L. Morawski, op. cit., s. 251-252.

${ }^{52}$ A. Patulski, op. cit., s. 129.
} 
zostało popełnione w czasie trwania nawiązywanego stosunku pracy - czyniłoby dalsze zatrudnienie niemożliwym ${ }^{53}$.

A. Drozd stwierdza zaś, że karalność jest w sposób oczywisty okolicznością, która podnosi ryzyko zatrudnienia nieodpowiedniego kandydata, a podmiot zatrudniający ma przecież interes, by dane stanowisko obsadzić kandydatem najlepszym. Nie każde przestępstwo jednak, za które kandydat został skazany, wpływa na poziom ryzyka zatrudnienia danej osoby, więc nie zawsze - pytając o karalność danej osoby - pracodawca będzie realizował swój usprawiedliwiony interes doboru najlepszej osoby do zatrudnienia na konkretne stanowisko. Dla oceny legalności pozyskania informacji o karalności poszukującego zatrudnienia konieczne jest występowanie w konkretnej sytuacji związku między ewentualnie popełnionym przestępstwem a stanowiskiem (rodzajem pracy), o które ubiega się kandydat $t^{54}$.

$\mathrm{W}$ mojej ocenie związek między popełnionym przestępstwem a rodzajem pracy będzie się wyrażał w tym, że sprawca czynu niedozwolonego naruszył te same obowiązki lub naraził na niebezpieczeństwo te same dobra, do czynienia z którymi będzie miał podczas wykonywania obowiązków na stanowisku pracy, co może po stronie pracodawcy rodzić uzasadnione obawy, czy pracownik ten będzie wykonywał swoją pracę w sposób sumienny i staranny, czy podporządkuje się pracodawcy i nie narazi go na szkody materialne, a przede wszystkim może powodować przekonanie, że wybór innego kandydata będzie się wiązał z mniejszym ryzykiem i większą pewnością (zaufaniem) między stronami stosunku pracy. Związki między rodzajem pracy a popełnionym przestępstwem najłatwiej zobrazować przykładem. Oczywisty wpływ w toku rekrutacji na stanowisko opiekunki do dzieci będzie miała karalność za przestępstwo znęcania się. Niemniej karalność za tego typu przestępstwo, jakkolwiek źle postrzegana w społeczeństwie, nie ma praktycznie żadnego związku z pracą magazyniera. $Z$ drugiej strony uprzednie skazanie za przestępstwa przeciwko mieniu może rodzić obawy przy poszukiwaniu pracowników na wiele stanowisk pracy, w szczególności związanych z powierzeniem pracownikowi mienia z obowiązkiem zwrotu albo do wyliczenia się, toteż w tym zakresie należy zachować szczególną ostrożność w różnicowaniu sytuacji kandydatów przy nawiązywaniu stosunku pracy.

\footnotetext{
${ }_{53}$ M. Święcicki, Prawo pracy, Warszawa 1968, s. 172.

54 A. Drozd, Prawo podmiotu zatrudniajacego do pozyskiwania informacji o kandydacie na pracownika, Warszawa 2004, s. 177-178.
} 


\section{PODSUMOWANIE}

Wprawdzie pojawiają się głosy, że żądanie w toku rekrutacji zaświadczenia o niekaralności ${ }^{55}$ bądź niezatrudnienie ze względu na uprzednią karalnośśc ${ }^{56}$ automatycznie stanowi dyskryminację, lecz w mojej ocenie stanowi to niedopuszczalne uproszczenie i pogląd taki nie może się ostać.

Należy zgodzić się, że dyskryminacja w nawiązywaniu stosunku pracy ze względu na karalność kandydata jest niedopuszczalna, oczywiście poza przypadkiem, gdy to ustawodawca nakłada na pracodawcę prawny obowiązek zatrudnienia osoby niekaranej za przestępstwa danego rodzaju - wtedy bowiem nie może być mowy o dyskryminacji, dopóki pracodawca porusza się w ramach nakreślonych normą prawną.

Niemniej dopuszczalne jest różnicowanie sytuacji zainteresowanych znalezieniem zatrudnienia ze względu na fakt uprzedniego skazania pod warunkiem, że działanie takie nie będzie zachowaniem dyskryminacyjnym, a zatem gdy będzie wynikało z obiektywnych i rozsądnych przyczyn. Z tego powodu, za S.W. Ciupą, kryterium karalności winno być zaliczone do tzw. białej listy, a więc nie pociąga za sobą automatycznie domniemania, że doszło do dyskryminacji, ale niezbędne jest przeprowadzenie analizy całokształtu konkretnych okoliczności związanych z selekcją i rekrutacją. W uzasadnieniu wyroku Sądu Najwyższego z dnia 5 października $2007 \mathrm{r} .{ }^{57}$ stwierdzono, że uprawnienie pracodawcy do kształtowania takich zasad naboru pracowników, które najpełniej odpowiadają jego potrzebom, nie może być kwestionowane. Chociaż pracodawca de facto nie ma możliwości żądać od pracownika podania informacji z KRK, to wielokrotnie w toku rekrutacji takie wiadomości poweźmie, m.in. z uwagi na wolność komunikowania się. Nie sposób przyjąć, że w pewnych sytuacjach fakt uprzedniej karalności (w szczególności wielokrotnej) powinien pozostać bez wpływu na obdarzenie kandydata zaufaniem, a w rezultacie bez wpływu na ewentualne nawiązanie stosunku pracy. W wielu przypadkach nie będzie to miało nic wspólnego z dyskryminacją, pod tym jednak warunkiem, że okoliczności popełnienia przestępstwa i zakres obowiązków na danym stanowisku pracy będą ze sobą w sposób oczywisty kolidować.

${ }^{55}$ Por. K. Bogatko, Dyskryminacja ze względu na karalnośćc, www.prawaczlowieka.edu.pl/ index.php?dok=014a1aa3f7a2c6578a3fa48e3dd84f775925489f-d3 [dostęp: 10.10.2016].

56 Por. eadem, Równe traktowanie w odniesieniu do zatrudnienia pracowniczego i niepracowniczego, www.ptpa.org.pl/site/assets/files/1029/poradnik_dla_osob_slabowidzacych_-_rowne_traktowanie_w_odniesieniu_do_zatrudnienia_pracowniczego_oraz_niepracowniczeg.pdf $\overline{\text { [do- }}$ [dostęp: 10.10.2016].

${ }^{57}$ II PK 14/07, Lex nr 898818. 


\section{BIBLIOGRAFIA}

Bogatko K., Dyskryminacja ze względu na karalność, www.prawaczlowieka.edu.pl/index.php?do

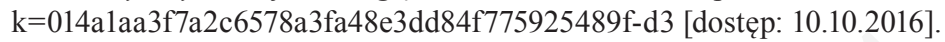

Bogatko K., Równe traktowanie $w$ odniesieniu do zatrudnienia pracowniczego i niepracowniczego, www.ptpa.org.pl/site/assets/files/1029/poradnik_dla_osob_slabowidzacych_-_rowne_traktowanie_w_odniesieniu_do_zatrudnienia_pracowniczego_oraz_niepracowniczeg. pdf [dostęp: 10.10.2016].

Brayshaw L., Chrobot A., Konior E., Płucienik A., Wanio G., Derekrutacja, czyli jak skutecznie rozwiazać stosunek pracy, Warszawa 2015.

Cajsel W., Kodeks pracy. Komentarz, Warszawa 2007.

Ciupa S.W., Naruszenie zakazu dyskryminacji w zatrudnieniu w praktyce korzystania z ogłoszeń rekrutacyjnych, cz. 1: Dyskryminacja ze względu na płeć, wiek, niepetnosprawność, wymóg spetnienia określonych obowiązków lub innych rygorów, „Praca i Zabezpieczenie Społeczne" 2006, nr 11.

Drozd A., Ochrona danych osobowych pracownika (kandydata) po nowelizacji kodeksu pracy, „Praca i Zabezpieczenie Społeczne” 2004, nr 1.

Drozd A., Prawo podmiotu zatrudniajacego do pozyskiwania informacji o kandydacie na pracownika, Warszawa 2004.

Drozd A., Wypowiedzenie stosunku pracy, Wrocław 2013.

Dyrektywa Rady 2000/78/WE z dnia 27 listopada 2000 r. ustanawiająca ogólne warunki ramowe równego traktowania w zakresie zatrudnienia i pracy (Dz.Urz. WE L 303 z dnia 2 grudnia 2000 r.).

Florek L., Prawo pracy, Warszawa 2015.

http://sjp.pwn.pl [dostęp: 12.09.2016].

Jamka B., Kierowanie kadrami: pozyskiwanie i rozwój pracowników, Warszawa 1997.

Kędziora K., Śmiszek K., Dyskryminacja i mobbing w zatrudnieniu, Warszawa 2010.

Konstytucja Rzeczypospolitej Polskiej z dnia 2 kwietnia 1997 r. uchwalona przez Zgromadzenie Narodowe w dniu 2 kwietnia 1997 r., przyjęta przez Naród w referendum konstytucyjnym w dniu 25 maja 1997 r., podpisana przez Prezydenta Rzeczypospolitej Polskiej w dniu 16 lipca 1997 r. (Dz.U. z 1997 r., nr 78, poz. 483).

Kowalska A., Pracownik w firmie od przyjęcia do zwolnienia, Warszawa 2013.

Król J., Nowelizacja Kodeksu pracy dotyczaca równego traktowania w zatrudnieniu na tle regulacji wspólnotowych, „Radca Prawny” 2004, nr 4.

Lankamer A., Potocka-Szmoń P., Dyskryminacja w miejscu pracy. Poradnik dla pracodawcy i pracownika, Gdańsk 2006.

Lenart B., Dyskryminacja w pracy bezwzględnie zakazana. Przepisy ogólne. Równe traktowanie w zatrudnieniu, „Gazeta Prawna” 2004, nr 24.

Leszczyńska A., Utrata zaufania do pracownika jako przyczyna wypowiedzenia umowy o prace, [w:] Ochrona trwałości stosunku pracy w społecznej gospodarce rynkowej, red. G. Goździewicz, Warszawa 2010.

Leszczyński L., Zagadnienia teorii stosowania prawa. Doktryna i tezy orzecznictwa, Kraków 2004.

Morawski L., Zasady wykładni prawa, Toruń 2010.

Orzeczenie Trybunału Konstytucyjnego z dnia 3 września 1996 r., K 10/96, OTK 1996, nr 4, poz. 33.

Patulski A., [w:] A. Patulski, G. Orłowski, Kodeks pracy 2015. Komentarz dla praktyków, Gdańsk 2015.

Podręcznik europejskiego prawa o niedyskryminacji, Agencja Praw Podstawowych Unii Europejskiej 2010, Rada Europy 2012. 
Postanowienie Sądu Najwyższego z dnia 11 kwietnia 2012 r., I PK 224/11, Lex nr 1220787.

Raczkowski B., Dyskryminacja bez dyskryminacji. Dylematy. Rozbieżność prawa polskiego i unijnego, „Gazeta Prawna” 2004, nr 122.

Roguska-Kikoła A., Piwowarska-Reszka M., Mobbing i dyskryminacja w stosunkach pracy. Zagadnienia praktyczne, Warszawa 2014.

Sanetra W., [w:] J. Iwulski, W. Sanetra, Komentarz do Kodeksu pracy, Warszawa 2009.

Skoczyński J., Zasada równego traktowania pracowników, „Praca i Zabezpieczenie Społeczne” 1999, nr 7-8.

Sobczyk A., [w:] Kodeks pracy. Komentarz, red. A. Sobczyk, Warszawa 2014.

Suchar J.A., Jak uniknać dyskryminacji w procesie rekrutacji i selekcji pracowników, Gdańsk 2013.

Suchar M., Rekrutacja i selekcja personelu, Warszawa 2005.

Święcicki M., Prawo pracy, Warszawa 1968.

Ustawa z dnia 26 czerwca 1974 r. - Kodeks pracy (Dz.U. z 1974 r., nr 24, poz. 141).

Ustawa z dnia 6 czerwca 1997 r. - Kodeks karny (Dz.U. z 1997 r., nr 88, poz. 553).

Ustawa z dnia 24 maja 2000 r. o Krajowym Rejestrze Karnym (Dz.U. z 2012 r., poz. 654 ze zm.).

Ustawa z dnia 14 listopada 2003 r. o zmianie ustawy - Kodeks pracy oraz o zmianie niektórych innych ustaw (Dz.U., nr 213, poz. 2081).

Ustawa z dnia 21 listopada 2008 r. o służbie cywilnej (Dz.U. z 2014 r., poz. 1111 ze zm.).

Walencik I., Sprawdzanie niekaralności, „Rzeczpospolita” 2004 (10 maja).

Wujczyk M., [w:] Wypowiedzenie warunków pracy lub płacy w umownym stosunku pracy, red. Z. Góral, Warszawa 2015.

Wujczyk M., Prawo pracownika do ochrony prywatności, Warszawa 2012.

Wyrok Sądu Najwyższego z dnia 25 listopada 1997 r., I PKN 385/97, OSNP 1998, nr 18, poz. 538. Wyrok Sądu Najwyższego z dnia 27 listopada 1997 r., I PKN 387/97, OSNP 1998, nr 19, poz. 569. Wyrok Sądu Najwyższego z dnia 9 grudnia 1998 r., I PKN 498/98, OSNP 2000, nr 3, poz. 104.

Wyrok Sądu Najwyższego z dnia 7 kwietnia 1999 r., I PKN 668/98, OSNP 2000, nr 11, poz. 429. Wyrok Sądu Najwyższego z dnia 31 marca 2001 r., I PKN 212/00, OSNP 2002, nr 19, poz. 458. Wyrok Sądu Najwyższego z dnia 14 października 2004 r., I PK 697/03, MPP 2005, nr 10. Wyrok Sądu Najwyższego z dnia 5 października 2007 r., II PK 14/07, Lex nr 898818. Wyrok Sądu Najwyższego z dnia 4 lutego 2011 r., II PK 199/10, OSNP 2012, nr 7-8, poz. 90. Wyrok Sądu Najwyższego z dnia 2 października 2012 r., II PK 82/12, OSNP 2013, nr 17-18, poz. 202.

Wyrok Sądu Najwyższego z dnia 7 lutego 2013 r., III PK 25/12, Lex nr 1360270.

Wyrok Trybunału Konstytucyjnego, U 3/01, OTK-A 2002/1/3.

Ziółkowski P., Zatrudnianie pracowników, [w:] Vademecum Głównego Księgowego, www.produkty.lex.pl/glowny-ksiegowy [dostęp: 10.10.2016].

\section{SUMMARY}

Employee rights are protected by the Labour Code and other labor laws. Protective function of this branch of law is fullfilled, among others, by provisions on the prohibition of discrimination. In certain circumstances, the provisions provide legal protection also for candidates for employees, indicating what a potential employer may require from the candidate, how he should behave towards him and what are the permitted criteria for evaluating job-seeker in the course of the recruitment for the position. Discrimination may therefore occur at the stage of looking for a job by a potential employee, especially during the recruitment procedure. The Labour Code contains open catalog of causes of discrimination, and therefore often appear doubts as to whether the 
action of the employer bears the hallmarks of discrimination, whether it is an acceptable action. Because of this, it is reasonable to attempt to answer the question whether it is permissible to differentiate the situation of candidates for jobs at employment relationships due to a prior criminal record. This will determine the relationship between the discretionary power of the employer to choose the best candidate for the job, and the equal treatment of all potential employees, including due to the content of their criminal cards.

Keywords: labor law; discrimination; criminal convictions; sentencing; recruitment 